SHORT COMMUNICATION

\title{
Metriura Drolshagen \& Bäckstam, 2009 (Araneae: Dipluridae) is a junior synonym of Fufius Simon, 1888 (Araneae: Cyrtaucheniidae)
}

\author{
Rogério Bertani ${ }^{1,2}$, Caroline Sayuri Fukushima' \& Roberto Hiroaki Nagahama ${ }^{1}$ \\ ${ }^{1}$ Laboratório Especial de Ecologia e Evolução, Instituto Butantan. Avenida Vital Brazil 1500, 05503-900 São Paulo, SP, Brazil. \\ ${ }^{2}$ Corresponding author. E-mail: rbert@butantan.gov.br
}

\begin{abstract}
The monotypic diplurid Metriura Drolshagen \& Bäckstam, 2009 is placed in synonymy with Fufius (Cyrtaucheniidae) syn. nov. since Metriura lacks two of three diplurid synapomorphies (elongate posterior lateral spinnerets and the widely separated posterior median spinnerets) and shares synapomorphies with both aporoptychine cyrtaucheniids (subquadrate maxilla and a longer than wider labium) and Fufius (recurved and broad fovea, the typical incrassate tibia I of the male, with the spur having a single short branch and an apical megaspine, the basally curved metatarsus I and provided with a ventral tubercle). The type species of Metriura, M. striatipes Drolshagen \& Bäckstam, 2009 is considered valid, and due to the synonymy of Metriura with Fufius, Fufius striatipes (Drolshagen \& Bäckstam, 2009) comb. nov. is established.
\end{abstract}

KEY WORDS. Amazon; Mygalomorphae; synonymy; taxonomy.

Dipluridae was characterized by Raven (1985) by the following synapomorphies: elongated posterior lateral spinnerets, widely separated posterior median spinnerets, and a lowered caput plus thoracic region elevated. The eight genera known from South America have been included in four subfamilies (Raven 1985): Diplurinae (Diplura C.L. Koch, 1850; Trechona C.L. Koch, 1850; Linothele Karsch, 1879), Masteriinae (Masteria L. Koch, 1873; Striamea Raven, 1981), Ischnothelinae (Ischnothele Ausserer, 1875; Andethele Coyle, 1995), and Euagrinae (Chilexops Coyle, 1986). Later, Maréchal \& Marty (1998) revalidated Harmonicon Pickard-Cambridge, 1896 (Diplurinae); and, recently, Drolshagen \& Bäcкstam (2009) described the monotypic Metriura Drolshagen \& Bäckstam, 2009 from Brazil, for Metriura striatipes Drolshagen \& Bäckstam, 2009. The authors did not explain their reasons for including their new genus in Dipluridae, but considered that Metriura belongs to Diplurinae because of the presence of two rows of teeth on the paired tarsal claws. They distinguished Metriura from Diplura, Trechona, and Harmonicon by the absence of a prolateral lyra on the maxillae, and from Linothele by the presence of a broader and longer labiosternal suture, two erect foveal setae in front of the fovea, a strongly curved base on metatarsus I, and a longer cymbium in males. They named the new genus "Metriura", which means "medium tail" in Greek, referring to the moderately long posterior lateral spinnerets.

The detailed original account of the male holotype of $M$. striatipes describes a specimen with two rows of teeth on superior tarsal claws, a long and slender embolus, a male spur with a single branch having an apical megaspine, a basally curved metatarsus I and a tubercle at the medial portion of the retroventral metatarsus I. These characteristics are compatible with diplurids but are not exclusive to the family. Conversely, the holotype has the labium longer than wider, subquadrate maxillae, and tarsi short and not pseudosegmented, which are not diplurinid characteristics (RAVEN 1985). Furthermore, the original description of $M$. striatipes does not include an illustration of the spinnerets, which are structures fundamental for assigning the species to the Dipluridae, since two of the three synapomophies of the family (RAVEN 1985) are related to these structures. Therefore, the inclusion of Metriura in Dipluridae is questionable and we herein reinterpret its taxonomic position. In order to clarify the question, we reanalyzed the morphological characteristics provided in the description of $M$. striatipes based on voucher specimens and photographs of additional structures of the holotype. Specimens examined in this paper are deposited at the Instituto Nacional de Pesquisas da Amazônia, Manaus (INPA), at the Muséum national d'Histoire naturelle, Paris (MNHN), and the Museu Nacional, Rio de Janeiro (MNRJ).

Our study indicates that Metriura is not a diplurid because it lacks two of the three synapomorphies of the family; i.e., the posterior lateral spinnerets are not elongated and the posterior median spinnerets are not widely separated (Fig. 1). Moreover, the species resembles an aporoptychine cyrtaucheniid. Aporoptychines are characterized by a subquadrate maxilla, labium almost as long as wide or longer, a short diagonal fang, 


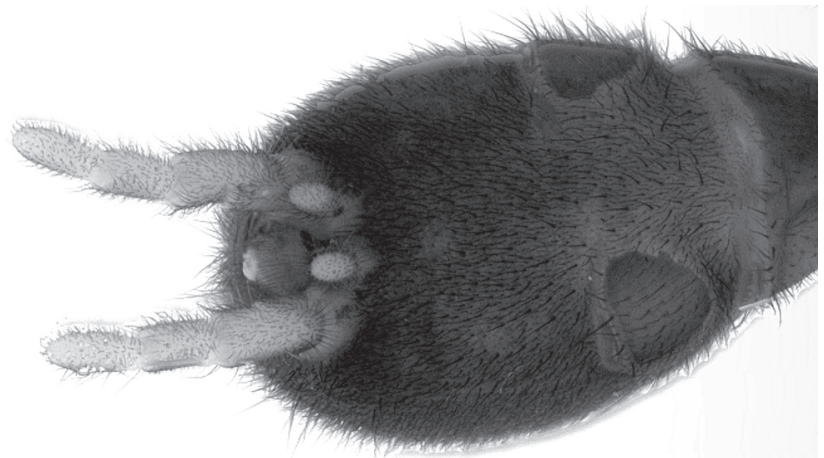

Figure 1. Fufius striatipes comb. nov., holotype male. Ventral aspect of abdomen, showing spinnerets.

and the associated short fang groove (RAVEN 1985). A subquadrate maxilla and a labium that is longer than wide, two cyrtaucheniid characteristics, are clearly visible in the illustration of the holotype provided by Drolshagen \& BäcKstam (2009).

Other characteristics, such as a recurved and broad fovea, the typical incrassate tibia I of the male, with the spur having a single short branch and an apical megaspine, the basally curved metarsus I (RAVEN 1985) and provided with a ventral tubercle are all characteristics of species of Fufius Simon, 1888 (Cyrtaucheniidae Simon, 1889). In addition, the presence of "legs with distinct pattern consisting of 1-2 stripes on all segments except tarsi" (Drolshagen \& BäcKstam 2009) in the juvenile paratype is also compatible with Fufius. The presence of this leg pattern is a common juvenile characteristic of many species of Fufius and may completely disappear when the specimen reaches maturity. All characteristics presented in the description, as well as those obtained by us, are compatible with the cyrtaucheniid Fufius. Therefore, the diplurid Metriura Drolshagen \& Bäckstam, 2009 is here considered a junior synonym of the cyrtaucheniid Fufius Simon, 1888 syn. nov.; and, consequently, M. striatipes is transferred to Fufius striatipes (Drolshagen \& Bäckstam 2009) comb. nov.. Examination of most of the holotypes of the known species of Fufius indicates that F. striatipes is a valid species.

\section{TAXONOMY}

\section{Fufius Simon, 1888}

Fufius Simon, 1888: 213 (type species by monotypy Fufius atramentarius Simon, 1888; female holotype in MNHN, examined); Platnick, 2012.

Hapalothele (in part: H. albovittata Simon, 1891: 306; $H$. auricomus Simon, 1891: 305; H. lanicia Simon, 1892: 283).

Brachythele (in part: B. antillensis F.O.P.-Cambridge, 1898: 899).

Phrissaecia Simon, 1892: 274 (type species by monotypy Phrissaecia ecuadorensis Simon, 1892). First synonymized by Simon, 1903: 967.
Hermorhachias Mello-Leitão, 1941: 234 (type species by original designation Hermorhachias annulipes Mello-Leitão, 1941). First syonymized by Raven, 1985: 134.

Metriura Drolshagen \& Bäckstam, 2009: 365 (type species by monotypy Metriura striatipes Drolshagen \& Bäckstam, 2009); Platnick, 2012. syn. nov.

\section{Fufius striatipes (Drolshagen \& Bäckstam, 2009) comb. nov.;}

Metriura striatipes Drolshagen \& Bäckstam, 2009: 365; Platnick, 2012.

Type material examined: BrazIL, Amazonas: Manaus, Tarumã Mirim, $03^{\circ} 06^{\prime} 00^{\prime \prime} \mathrm{S}, 60^{\circ} 01^{\prime} 48^{\prime \prime} \mathrm{W}$, holotype male, Metriura striatipes Drolshagen \& Bäckstam, 2009, J. Adis leg., February 1982 (INPA 3507), examined by photographs; Manaos (sic), holotype male, Fufius albovittatus (Simon, 1891), Haunwell, MNHN (AR 7075, 9666); São Paulo: São Paulo, Parque Estadual da Serra da Cantareira, Núcleo Estadual da Pedra Grande, holotype male, Fufius lucasae Guadanucci \& Indicatti, 2004, C.C. Aires leg. (MZSP 23231). EcuAdor, Loja, holotype female, Fufius ecuadorensis (Simon, 1892), MNHN (AR 4948, 10582); GuateMALA, holotype female, Fufius atramentarius Simon, 1888, Perrot, MNHN (AR 4945; 8113).

Additional material examined. BraziL, Amazonas: Manaus, 2 males, Reserva Ducke 1501, km 41, Fazenda Esteio, L.E.R.E. Silva leg., 1995 (MNRJ 04518).

Description. See Drolshagen \& Bäckstam (2009).

Distribution. Known only from type locality, Manaus, Amazonas.

\section{ACKNOWLEDGMENTS}

We thank Christine Rollard for the loan of the type specimens of Fufius, and Ana Tourinho, Sidclay Dias, and Lidianne Salvatierra (INPA) for taking photos of the holotype of $M$. striatipes and allowing their use in this paper. We also thank Adriano Kury (MNRJ) for providing a repository for specimens.

\section{LITERATURE CITED}

Ausserer, A. 1875. Zweiter Beitrag zur Kenntniss der ArachnidenFamilie der Territelariae Thorell (Mygalidae Autor). Verhandlungen der k. k. zoologisch - botanischen Gesellschaft in Wien 25: 125-206.

Cambridge, F.O.P.-. 1896. On the Theraphosidae of the lower Amazons: being an account of the new genera and species of this group of spiders discovered during the expedition of the steamship "Faraday" up the river Amazons. Proceedings of the Zoological Society of London 1896: 716-766.

CAmbridge, F.O.P.-. 1898. On new species of spiders from Trinidad, West Indies. Proceedings of the Zoological Society of London 1898: 890-900. 
Coyle, F.A. 1986. Chilexops, a new funnelweb mygalomorph spider genus from Chile (Araneae, Dipluridae). American Museum Novitates 2860: 1-10.

Coyle, F.A. 1995. A revision of the funnelweb mygalomorph spider subfamily Ischnothelinae (Araneae, Dipluridae). Bulletin of the American Museum of Natural History 226: 1-133.

Drolshagen, B. \& C.M. Bäckstam. 2009. A new genus and species of the subfamily Diplurinae (Araneae, Dipluridae). Bulletin of the British Arachnological Society 14: 365-367.

GuADANUCCI, J.P.L. \& R.P. IndicatTI. 2004. Redescription of Fufius funebris Vellard, 1924 and description of Fufius lucasae sp. nov. with comments on Ctenochelus maculatus Mello-Leitão, 1923 (Mygalomorphae, Cyrtaucheniidae). Revista Ibérica de Aracnologia 10: 255-259.

KARSCH, F. 1879. Arachnologische Beitrage. Zeitschrift fur die gesammten Naturwissenschaften 52: 534-562.

Косн, L. 1873. Die Arachniden Australiens. Nürnberg 1, p. 369-472.

Косн, C.L. 1850. Übersicht des Arachnidensystems. Heft 5, Nürnberg, p. 1-77.

Maréchal, P. \& C. Marty. 1998. Réhabilitation du genre Harmonicon (Pickard-Cambridge, 1896) et description d'une nouvelle espèce de Guyana française (Araneae, Mygalomorphae, Dipluridae). Zoosystema 20: 499-504.

Mello-Leitão, C.F. 1941. Catalogo das aranhas da Colombia.
Anais da Academia Brasileira de Ciências 13: 233-300.

Platnick, N.I. 2012. The World Spider Catalog, version 12.5. American Museum of Natural History, New York. Available online at: http://research.amnh.org/iz/spiders/catalog [Accessed: 16/III/2012].

RAVEN, R.J. 1981. Three new mygalomorph spider (Dipluridae, Masteriinae) from Colombia. Bulletin of the American Museum of Natural History 170: 57-63.

RAVEN, R.J. 1985. The spider infraorder Mygalomorphae (Araneae): cladistics and systematics. Bulletin of the American Museum of Natural History 182: 1-180.

Simon, E. 1888. Etudes arachnologiques. 21e Mémoire. XXIX. Descriptions d'espèces et de genres nouveaux de l'Amérique centrale et des Antilles. Annales de la Societe Entomologique de France (6) 8: 203-216.

Simon, E. 1891. Etudes arachnologiques. 23e Mémoire. XXXVIII. Descriptions d'espèces et de genres nouveaux de la famille des Aviculariidae. Annales de la Societe Entomologique de France 60: 300-312.

Simon, E. 1892. Etudes arachnologiques. 24e Mémoire. XXXIX. Descriptions d'espèces et de genres nouveaux de la famille des Aviculariidae (suite). Annales de la Societe Entomologique de France 61: 271-284.

SimON, E. 1903. Histoire naturelle des araignées. Libraire Encyclopédique de Roret, Paris, vol. 2, p 669-1080.

Submitted: 18.IV.2012; Accepted: 28.V.2012.

Editorial responsibility: Walter A.P. Boeger 